\title{
特集「東アジア地域における食料流通・食品の安全確保と 情報技術の応用」について
}

\author{
南石晃明*1)
}

1）九州大学大学院農学研究院

\section{はじめに}

本特集は, 平成 20 年 3 月 18 日 (火), 東京大学弥生講堂 において開催された日本学術会議公開シンポジウム「東ア ジア地域における食料流通・食品の安全確保と情報技術の 応用」における講演論文を収録したものである. シンポジ ウムにおける質疑やパネルディスカッションの成果を踏ま えて加筆修正を頂き, 通常の原著論文と同様の審査を経て 掲載するものである.

このシンポジウムでは, 東アジア地域主要国の最新の動 向が把握できるように日本に加えて, 中国, 韓国, タイか らもご講演を頂いた。 これらの優れた論文をできるだけ多 くの方々にご紹介すべく, 主催機関の 1 つとしてシンポジ ウム実行委員会を組織した農業情報学会では, 本誌におけ る特集を当初から予定していた。論文審査のため, 特集論 文刊行にやや時間を要する結果となったが, 価值ある特集 になったと考えている.

\section{シンポジウムの目的と概要}

食料・食品の安全確保が契緊の課題であることは論を俟 たない. 本シンポジウムでは, 特に情報技術の果たす役割 とその応用可能性を検討することを目的として開催された ものである．輸入農産物に依存するわが国にとって食料の 流通と安全確保は重要な課題である。そこで, 本シンポジ ウムでは, 東アジア地域の農水産物の流通とそこにおける 安全確保に向けた課題やリスク認知, コミュニケーション 技術, GAP などの標準化の重要性について, 講演とパネル ディスカッションを行った（野口 2008). パネルディスカッ ションでは, 東アジア地域のトレーサビリティや GLOBALGAP，コンプライアンスに関する先端的取り組み の紹介を含めて, 食料流通・食品の安全確保に向けた課題

* Corresponding Author

E-mail: nanseki@agr.kyushu-u.ac.jp
について討論し, 今後の方向を探った.

シンポジウムの概要を以下に示す.

日本学術会議公開シンポジウム

「東アジア地域における食料流通・食品の安全確保と情報 技術の応用」

1. 主催 日本学術会議農学基礎委員会農業情報システム 学分科会, 日本学術会議農学基礎委員会食の安全分科会, 日本学術会議生産農学委員会水産学分科会, 日本学術会 議農学基礎委員会農業経済学分科会, 農業情報学会, 東 京大学大学院農学生命科学研究科

2. 共催 日本農業経営学会, フードシステム学会, 農業 施設学会, 農業機械学会, アジア農業工学会

3. 日 時 平成 20 年 3 月 18 日（火） 13:00 17:30

4. 場 所 東京大学弥生講堂（東京都文京区弥生 1-1-1 東京大学農学部内）

\section{特集論文の構成と概要}

特集論文の構成と概要は, 以下に示すとおりである. 第 1 に, Athapol Noomhorm 氏（AIT アジア工科大教授）には, 「Food Supply Chain Management and Food Safety: South \& East-Asia Scenario」と題し, タイ, 日本, 韓国, 北朝鮮, 中 国における食料・農業産業の現状について, フードサプラ イチェーンと食の安全をキーワードとして概観頂いた。第 2 に, 李喆熙氏 (Cheol-Hi Lee, 韓国農村振興庁) には, 「韓 国における農産物安全システムの現状と発展方向」と題し, トレーサビリティ, GAP, 食品安全をキーワードとして, 韓国の現状と今後の展開を述べて頂いた。第 3 に，一色賢 司氏（北海道大学大学院水産科学研究院教授）には, 「水産 物等の安全性確保とフードチェーン・アプローチ」と題し, 食品安全, フードチェーン, リスク分析, 水産物, コール ドチェーンをキーワードとして, 食品のリスク分析（アナ リシス）とフードチェーン・アプローチの考え方ついて， 主に我が国の事例を取り上げ述べて頂いた，第 4 に，新山 
陽子氏（京都大学大学院農学研究科教授）には,「食品安全 の考え方と措置の枠組み」と題し, 食品安全の国際的枠組 み, 食品安全確保の考え方と手法, レギュラトリーサイエ ンス等をキーワードとして, フードチェーンにおける農業 者, 食品製造・流通事業者の食品安全対策全般について述 べて頂いた，第 5 に，筆者は「食の安全確保と情報技術の 展望」と題し, 次世代フードシステム, 情報通信技術 ICT, 持続可能性, 環食不二, 食農資環リスク学をキーワードと して, 情報通信技術 ICT が食の安全確保において果たす役 割について展望している.

誌幅の制約から下記論文については, 本誌次号への掲載 を予定している. 永木正和氏（筑波大学大学院生命環境科 学研究科教授) には,「アジア圏の食の流通と安全確保への 展望」と題し, 安全と安心, フード・システム, 情報力, GAP, 関係性の経済をキーワードとして, 日本型 CSA の構 築について展望を述べて頂く予定である. なお, 中国農業 科学院宋敏教授のシンポジウム講演論文「Food Traceability System and Consumers' Attitude to It in China-Evidences from the Pork Market in Beijing」（Min Song 2008）について
は, 本特集への投稿を見送られたが, 別途公表されると伺っ ている.

おわりに

本特集が, 東アジア地域における食料・食品の安全確保 と情報技術の応用に関する読者の理解を助け, 問題解決に 向けた一助となれば幸いである。本特集の趣旨に賛同・承 諾頂いた日本学術会議農業情報システム学分科会を始めと する関係各位に, 農業情報学会シンポジウム実行委員会委 員長および特集論文編集者として厚く御礼申し上げます。

\section{引用文献}

野口 伸（2008）はじめに, 日本学術会議公開シンポジウム「東 アジア地域における食料流通・食品の安全確保と情報技術の 応用」, 講演要旨集, 1 . $\begin{array}{lr}\text { 受付日 } & \text { 2008年 8月14日 } \\ \text { 受理日 } & \text { 2008年 9月17日 } \\ \text { 担当部会 } & \text { 生産・経営情報部会 }\end{array}$

\title{
On Special Issues \\ "Securement of Food Distribution \& Food Safety and Important Role of IT in East Asian Countries"
}

\author{
Teruaki Nanseki*1)
}

1) Faculty of Agriculture, Kyushu University

\footnotetext{
* Corresponding Author

E-mail: nanseki@affrc.go.jp
} 